\title{
EFFECT OF UNIT EXERCISE ON HAND GRIP STRENGTH OF THE ARCHERS
}

\author{
Yonca Süreyya SEZER', Baha Engin ÇELIKEL ${ }^{2}$, Ercan GÜR $R^{3}$, Yüksel SAVUCU \\ ${ }^{1-4}$ University of Firat, Faculty of Sports Sciences, Elazig / Turkey
}

ORCID ID: 0000-0003-3072-8302 , 0000-0002-8429-969X $X^{2}, 0000-0001-6690-828 X^{3}, 0000-0002-2749-6806^{4}$

Öz: Amaç: Araştırmanın amacı erkek okçularda bir birim antrenman öncesinde ve antrenman sonrasında el kavrama kuvvetindeki değişimin değerlendirilmesidir. Araştırmaya Elazığ ili gençlik spor müdürlüğü okçuluk takımı 16-19 yaş grubu, ( $\mathrm{n}=16)$ sporcusu dahil edildi. Yöntem: Araştırma kapsamında deney grubuna antrenmana başlama öncesinde tüm test ve ölçümler (yaş, boy, vücut ağırlığı, spor yaşı, el kavrama kuvveti testi) yapıldıktan sonra antrenman bitiminin hemen ardından da aynı testler tekrarlanıp değerlendirildi. Bir birim antrenman programı ise okçuluk takımı antrenörünün uyguladığı o günün plan ve programda olan 1sınma, soğuma ve hedefe 200 ok atışından oluşturuldu. İstatistiksel analizlerinde tanımlayıcı istatistik yapıldı, egzersiz öncesi ve sonrası el pençe kuvvetleri arasındaki anlamlılık düzeylerinin belirlenmesinde ise eşleştirilmiş örneklemler t testi analizi yapıldı. Analizlerde önem düzeyi 0.05 olarak gösterildi. Bulgular: Sporcuların sağ el pençe kuvveti $(n=16)$ egzersiz öncesinde $41,4250 \pm$ 2,24892 iken egzersiz sonrasinda $42,2875 \pm 2,24870$ $(\mathrm{p}<0,05)$, sol el pençe kuvveti ise egzersiz öncesinde $39,2125 \pm 2,04811$ iken egzersiz sonrasında 39,3938 \pm $2,12762(p<0,05)$ değerleri ile anlamlı bulundu. Sonuç: Sonuç olarak okçuluk sporcularında bir birim antrenman sonunda el kavrama kuvvetinde istatistiksel olarak pozitif yönde anlamlı bir artış olduğu görüldü. Bunun sebebinin ise antrenmanın orta şiddette doğru teknik hareketleriyle yapılmasından dolayı kas içi 1sı ve koordinasyonun ve motivasyonun tam sağlanmasına bağlı olduğu söylenebilir.

Anahtar Kelimeler: Okçuluk, El Kavrama Kuvveti, Ok Atış Antrenmanı
Abstract: Objective: The purpose of this study is to evaluate the difference of hand grip strength for male archers before and after one unit exercise. The study incorporated sportsmen of 16-19 $(n=16)$ from the archery team of Elazığ Provincial Directorate of Youth and Sports. Method: All tests and evaluations (age, height, body weight, sports age, hand grip strength test) applied to the experimental group before starting exercise under the research were applied to the sportsmen immediately after the end of the exercise and relevant evaluations made. One unit exercise program consisted of the warm-up, cool down and shooting 200 arrows on target which were scheduled by the coach of the archery team for that day. For descriptive statistics analysis, paired t-test was utilized to determine the significance levels of hand grip strengths before and after the exercise. Significance level was indicated as 0.05 in analysis. Results: While the right hand grip strength of the sportsmen $(\mathrm{n}=16)$ was $41,4250 \pm 2,24892$ before the exercise, it was found significant as 42,2875 $\pm 2,24870(p<0,05)$ after the exercise, and left hand grip strength determined as $39,2125 \pm 2,04811$ before the exercise was found significant as $39,3938 \pm 2,12762$ $(p<0,05)$ in the aftermath. Conclusion: Consequently, it is no wrong to say that a statistically positive increase was observed on the hand grip strengths of the archery sportsmen following a unit of exercise, and this was linked to the complete in-muscle warming and coordination due to exercise performed with moderate, correct techniques.

Key Words: Archery, Hand Grip Strength, Arrow Shooting Exercise

Doi: $10.17363 /$ SSTB.2017.3.1

(1) Corresponding Author: A. Serdar YÜCEL, Firat University, Faculty of Sports Sciences, Elazig / Turkey, alsetu_23@ hotmail.com, Received: 07.05.2017, Accepted: 21.09.2017, Type ofarticle (Research -Application) Conflict of Interest: None / "None of Ethics Committee" 


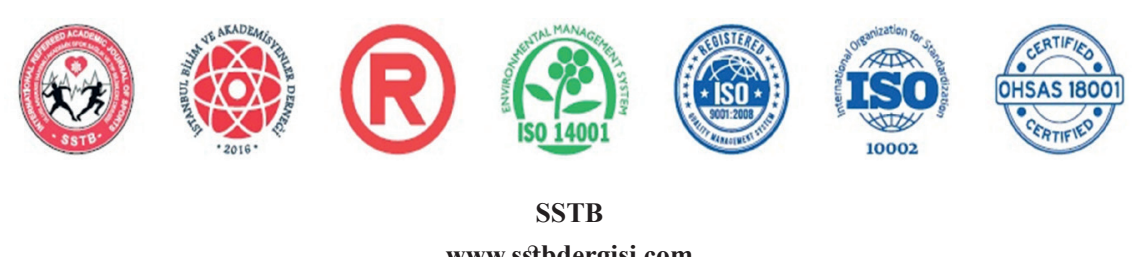

www.sstbdergisi.com

International Refereed Academic Journal of Sports, Health and Medical Sciences

July - August - September Issue 24 Summer Season Year: 2017

JEL CODE: H10-H11-L1-L2-L6-L10 ID:351 K:129

ISSN Print: 2146-8508 Online 2147-1711

(ISO 18001-OH-0090-13001706 / ISO 14001-EM-0090-13001706 / ISO 9001-QM-0090-13001706 / ISO 10002-CM-0090-13001706)

(TRADEMARK)

(2015/04315- 2015-GE-18972)

\section{INTRODUCTION}

Like shot, javelin and disk throwing are sports made with tools that are based on certain techniques and rules, archery is also a sport that is made with tools and consists of behaviours that should be performed technically interdependent and accordant ways. The goal in archery is also not getting a random success, but instead getting a deliberately earned bull's eye target success with a conscious and disciplined training (Ertan et al., 2005: 95-104). The most convenient time to begin archery is 12 to 14 years of age. And being a good archer takes 1.5 to 2 years. After initial period you pass onto youth group (16-18 years) and then to adults division which in total takes 4 to 6 years (http://bilginaticilik.com, 11.10.2017). In archery, almost all archers train over 1.52 hours in each training. This overlaps with the training hours applied in the world and with the training hours of high performance athletes. Analysing the training hours in relation to training efficiency, training quality and training programs for our archers to show higher performances can be the subject of other studies (Karanfilci et al., 2014: 112).

In archery which is an individual sport, the athletes pursues his competition until the evening with the throws beginning from the morning. The pulling weight of the bow is between 14-22 kg, changing from athlete to athlete. As 144 arrows are thrown during the competition, excluding the trials, the athlete would have lifted 144 x $20=2880 \mathrm{~kg}$ on average along the day (Kolayiş and Mimaroğlu, 2008: 11, 12).

Archery is defined as a sport that requires strength and endurance of the upper body, especially the shoulder muscles (Mann and Littke, 1989:85-92). Studies have shown that in an international event, a male archer pulls 45 pounds arc in a throw and during four days, he pulls at least 75 arcs a day (FITA 2006). This means that only in one day, approximately 3400 pounds $(1546 \mathrm{~kg})$ force in on the bone, bond and muscle structures (Karanfilci et al., 2014: 71).

Considering these numbers, it is seen that persistence in archery is important. However, the weight of the bow in each throw does not constitute the maximal strength. In one series of arrow throwing, each throw happens in 5 to 8 seconds on average. In this period, athlete must pull his arc, aim his target and complete his throw. There are many factors that affect this lining that appears to be very simple. We can separate these as internal and external factors. Internal factors can be ranged as arm and gripping strength, reaction time, concentration on the target, having sufficient condition and technical features and psychological condition. As for external factors, the sufficiency and convenience of the materials used, good weather conditions and quiet envi- 


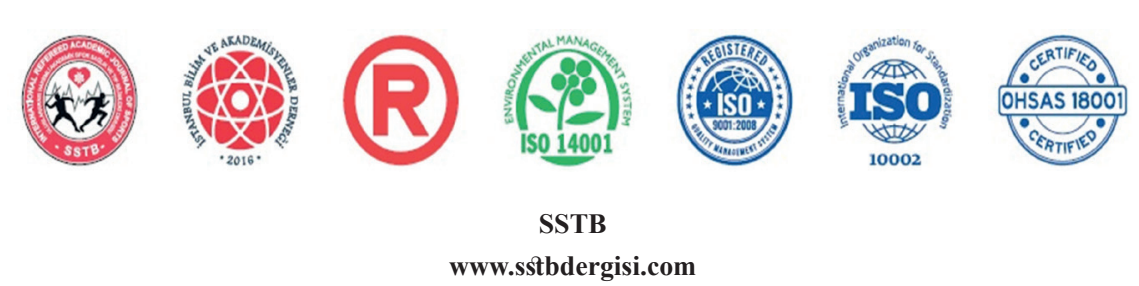

International Refereed Academic Journal of Sports, Health and Medical Sciences

July - August - September Issue 24 Summer Season Year: 2017

JEL CODE: H10-H11-L1-L2-L6-L10 ID:351 K:129

ISSN Print: 2146-8508 Online 2147-1711

(ISO 18001-OH-0090-13001706 / ISO 14001-EM-0090-13001706 / ISO 9001-QM-0090-13001706 / ISO 10002-CM-0090-13001706) (TRADEMARK)

(2015/04315- 2015-GE-18972)

ronment can be mentioned. Bringing all these qualities together, reaching at the highest arm strength performance might become difficult. As mentioned above, more than one factor in arm wrestling may affect the competition performance (Kolayiş and Mimaroğlu, 2008: 12).

The hand is one of the most important components of the upper extremity affecting its functionality. Among the functions of the hand, gripping is a function that is important for the continuity of the daily life activities (Angyan et al., 2003:227). Therefore, gripping strength is accepted as an objective measurement in the assessment of upper extremity performance. (Biçer, 2013:21-32)

Studies showed that, alongside with being correlated with upper extremity muscle strength, the hand gripping strength is also related with general body muscle strength and pulmonary muscle strength (Ertan et al., 2003:39).

For this reason, the aim of this study is to reveal changes in the hand gripping strength which can affect the competition of male archers before and after one unit training.

\section{MATERIAL and METHOD}

The sample of the study consists of 16 male athletes from 16-19 age group arm wrestling team of Firat University in Elazığ. The ages, heights, body weights and sport histories of the subjects in the study were given in Table 1 , together with their averages and standard deviations.

\section{Data Collection Tools}

To determine the individualistic qualifications of the subjects, first, the records about the athletes were analysed and interviews with the administrative personnel were performed, in which information on Firat University operation, and life and educational conditions of the students were acquired. The administrative personnel and the athletes were informed about the study to be conducted.

The study is performed by voluntary participation of the archery team athletes and within this scope, in the training hall of Furat Univer-

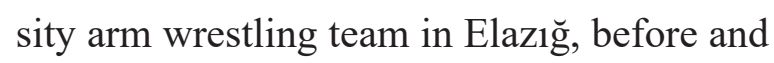
after 2 hours period of training, age, height, body weight, sport history and hand gripping strength test measurements were taken and assessed.

The one unit training program applied on the day the measurements were taken consisted of warm up, cool down, and 200 arrow throwing to the target which were in that day's plan and program applied by the trainer.

\section{Applied Tests and Measurements,}

1- Age (Age on the ID is used as a standard), 


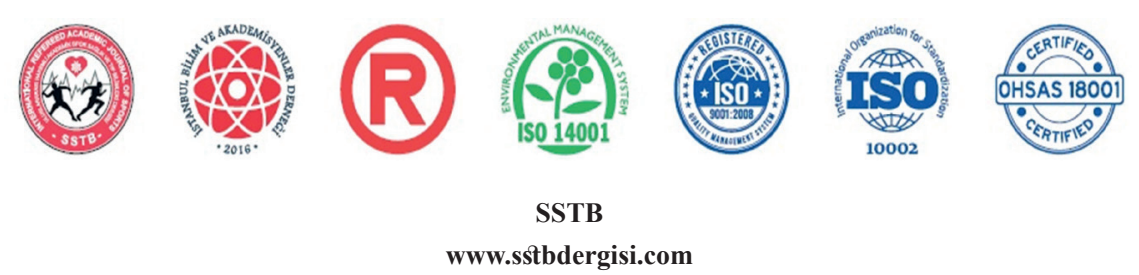

International Refereed Academic Journal of Sports, Health and Medical Sciences

July - August - September Issue 24 Summer Season Year: 2017

JEL CODE: H10-H11-L1-L2-L6-L10 ID:351 K:129

ISSN Print: 2146-8508 Online 2147-1711

(ISO 18001-OH-0090-13001706 / ISO 14001-EM-0090-13001706 / ISO 9001-QM-0090-13001706 / ISO 10002-CM-0090-13001706) (TRADEMARK)

(2015/04315- 2015-GE-18972)

2- Height (The device used is the height scale with $0.01 \mathrm{~m}$ sensitivity),

3- Body weight (The device used is the digital bascule with $0.01 \mathrm{~kg}$ sensitivity). The subjects were weighed on sensitive digital bascule (kg. unit) on bare foot and with only shorts on them. Height measurements were performed by subjects standing in upright position under the metal bar used fixedly in height scale. The metal bar was adjusted to remain on the head of the subject and the height was read on the metal bar in (cm) (Özer, 1992).

4- Sports age (The records of Elazığ Firat University arm wrestling team were used).

\section{5- Gripping strength measurement (The} device used is Jamar hydraulic dynamometer). The gripping strength was performed from right and left hand by "Hand Dynamometer". During the measurement, the subject stood upright on foot and the measurement was taken without bending the arm that is being measured, without letting it touch to the body and with a slight distance from the body. Same process was repeated three times both for right and left arm and the best value was recorded in kilograms (Özer, 1992).

\section{Statistical Analysis of the Data}

In the analysis of the averages and standard deviations of the demographic information, descriptive statistics was used; in determining the significance level between pre and post exercise hand gripping strength, paired sample $t$ test analysis was used. The results are combined by tabling. Data were analysed via 22.0 software SPSS package program. The significance level in analyses were shown to be $\alpha=0.05$ (Özdamar, 1999).

\section{FINDINGS}

Table 1. Averages and Standard Deviations of Demographical Information (Descriptive Statistics)

\begin{tabular}{llllll}
\hline \multicolumn{1}{r}{ Variables } & $\mathbf{N}$ & Min. & Max. & Mean & Std. Deviation \\
\hline Age & 16 & 16,00 & 19,00 & 17,8750 &, 91243 \\
\hline Height & 16 & 1,62 & 1,83 & 1,7350 &, 09921 \\
\hline Weight & 16 & 59,00 & 85,00 & 71,9375 & 8,74362 \\
\hline Sports Age & 16 & 1,00 & 3,00 & 2,0625 &, 57373 \\
\hline
\end{tabular}

When Table 1 is analyzed, it is observed that the average age of the participants is 0.09 , average weight is $71.93 \pm 8.74$ and their average athletic age is $2.06 \pm 0.5$. $17.87 \pm 0.91$, their average height is $1.73 \pm$ 


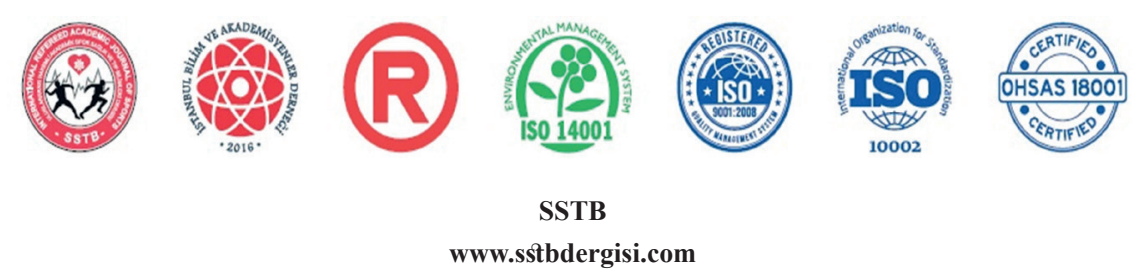

International Refereed Academic Journal of Sports, Health and Medical Sciences

July - August - September Issue 24 Summer Season Year: 2017

JEL CODE: H10-H11-L1-L2-L6-L10 ID:351 K:129

ISSN Print: 2146-8508 Online 2147-1711

(ISO 18001-OH-0090-13001706 / ISO 14001-EM-0090-13001706 / ISO 9001-QM-0090-13001706 / ISO 10002-CM-0090-13001706) (TRADEMARK)

(2015/04315- 2015-GE-18972)

Table 2. Averages and Standard Deviations of Hand Gripping Strength in The First Training (Descriptive Statistics)

\begin{tabular}{llllll}
\hline Variables & N & Min. & Max. & Mean & Std. Deviation \\
\hline Right - Before & 16 & 28,20 & 58,50 & 41,4250 & 5,67358 \\
\hline Right - After & 16 & 29,30 & 58,20 & 42,2875 & 5,94632 \\
\hline Left - Before & 16 & 27,80 & 51,50 & 39,2125 & 5,17963 \\
\hline Left - After & 16 & 37,30 & 55,40 & 39,3938 & 4,57823 \\
\hline
\end{tabular}

When Table 2 is analyzed, it is observed that strength is $39.21 \pm 5.17$ while the right hand the average right hand gripping strength before the training is $41.42 \pm 5.67$ and left hand gripping strength after the training is 42.28 \pm 5.94 and left hand is $39.9 \pm 4.57$.

Table 3. The Significance Level between Pre and Post Training Hand Gripping Strength in The First Training (Paired samples statistics).

\begin{tabular}{lllll}
\hline Variables & $\mathbf{N}$ & Before the exercise & After the exercise & $\mathbf{P}$ \\
\hline Right & 16 & $41,4250 \pm 2,24892$ & $42,2875 \pm 2,24870$ & 0,000 \\
\hline Left & 16 & $39,2125 \pm 2,04811$ & $39,3938 \pm 2,12762$ & 0,000 \\
\hline
\end{tabular}

According to Table 3, while the right hand gripping strength of athletes $(\mathrm{n}=16)$ is 41.4250 \pm 2.24892 before the training and $42.2875 \pm$ $2.24870(\mathrm{p}<0.05)$ after the training, left hand gripping strength is $39.2125 \pm 2.04811$ before the training and $39.3938 \pm 2.12762(\mathrm{p}<0.05)$ after the training and these values are significant.

Table 4. Averages and Standard Deviations of Hand Gripping Strength in The Second Training (Descriptive Statistics)

\begin{tabular}{llllll}
\hline Variables & N & Min. & Max. & Mean & Std. Deviation \\
\hline Right - Before & 16 & 30,40 & 60,70 & 43,3230 & 4,57151 \\
\hline Right - After & 16 & 31,50 & 60,40 & 45,1375 & 6,93132 \\
\hline Left - Before & 16 & 29,90 & 53,60 & 40,3145 & 4,67143 \\
\hline Left - After & 16 & 38,30 & 57,50 & 41,3621 & 5,87153 \\
\hline
\end{tabular}

According to Table 4, it is seen that the average right hand gripping strength of the par- ticipants before the training is $43.32 \pm 4.57$ and $40.31 \pm 4.67$ for the left hand and the right 


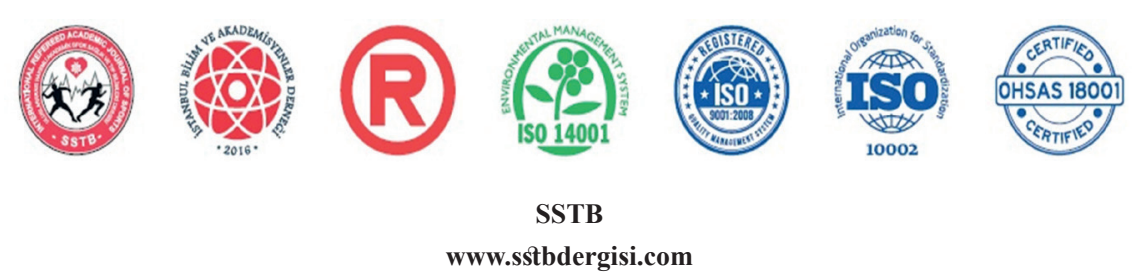

International Refereed Academic Journal of Sports, Health and Medical Sciences

July - August - September Issue 24 Summer Season Year: 2017

JEL CODE: H10-H11-L1-L2-L6-L10 ID:351 K:129

ISSN Print: 2146-8508 Online 2147-1711

(ISO 18001-OH-0090-13001706 / ISO 14001-EM-0090-13001706 / ISO 9001-QM-0090-13001706 / ISO 10002-CM-0090-13001706) (TRADEMARK)

(2015/04315- 2015-GE-18972)

hand value after the training is $45.13 \pm 6.93$

and $41.36 \pm 5.87$ for the left hand.

Table 5. The Significance Level between Pre and Post Training Hand Gripping Strength in The Second Training (Paired samples statistics).

\begin{tabular}{lllll}
\hline Variables & $\mathbf{N}$ & Before the exercise & After the exercise & P \\
\hline Right & 16 & $43,3230 \pm 2,21614$ & $45,1375 \pm 2,82621$ & 0,000 \\
\hline Left & 16 & $40,3145 \pm 2,02341$ & $41,3621 \pm 2,22282$ & 0,000 \\
\hline
\end{tabular}

According to Table 5, while the right hand gripping strength of athletes $(\mathrm{n}=16)$ is 43.3230 \pm 2.21614 before the training, it is $45.1375 \pm$ $2.82621(\mathrm{p}<0.05)$ after the training; left hand gripping strength is $40.3145 \pm 2.02341$ before the training and $41.3621 \pm 2.22282(\mathrm{p}<0.05)$ after the training and these values are significant.

Table 6. Averages and Standard Deviations of Hand Gripping Strength in The Third Training (Descriptive Statistics)

\begin{tabular}{llllll}
\hline Variables & N & Min. & Max. & Mean & Std. Deviation \\
\hline Right - Before & 16 & 31,20 & 60,42 & 44,5210 & 3,27151 \\
\hline Right - After & 16 & 32,21 & 61,15 & 45,1775 & 4,14232 \\
\hline Left - Before & 16 & 29,92 & 53,82 & 40,9135 & 3,37363 \\
\hline Left - After & 16 & 38,57 & 57,70 & 41,3938 & 2,47222 \\
\hline
\end{tabular}

According to Table 6, the average right hand fore the training while the right hand gripping gripping strength of the participants is $44.52 \quad$ strength is $45.17 \pm 4.14$ and left hand is 41.39 \pm 3.27 and $40.91 \pm 3.37$ for the left hand be- \pm 2.47 after the training.

Table 7. The Significance Level between Pre and Post Training Hand Gripping Strength in The Third Training (Paired samples statistics).

\begin{tabular}{lllll}
\hline Variables & $\mathbf{N}$ & Before the exercise & After the exercise & $\mathbf{P}$ \\
\hline Right & 16 & $45,5210 \pm 2,24892$ & $45,1775 \pm 2,34211$ & 0,000 \\
\hline Left & 16 & $40,9139 \pm 2,11711$ & $41,3938 \pm 2,22137$ & 0,000 \\
\hline
\end{tabular}




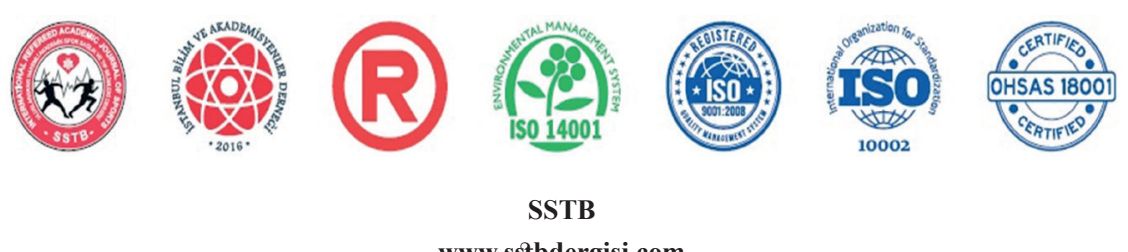

Www.sstbdergisi.com

International Refereed Academic Journal of Sports, Health and Medical Sciences

July - August - September Issue 24 Summer Season Year: 2017

JEL CODE: H10-H11-L1-L2-L6-L10 ID:351 K:129

ISSN Print: 2146-8508 Online 2147-1711

(ISO 18001-OH-0090-13001706 / ISO 14001-EM-0090-13001706 / ISO 9001-QM-0090-13001706 / ISO 10002-CM-0090-13001706) (TRADEMARK)

(2015/04315- 2015-GE-18972)

According to Table 7, while right hand gripping strength of athletes $(n=16)$ before the training is $44.5210 \pm 2.24892$, it is 45.1775 $\pm 2.34211(\mathrm{p}<0.05)$ after the training; left hand gripping strength before the training is $40.9139 \pm 2.11711$ and it is $41.3938 \pm 2.22137$ $(p<0.05)$ after the training and these values are significant.

\section{DISCUSSION}

The most important finding of this study was that the training improves the hand gripping strength performance of the archers significantly. In the age, height, weight and sport history measurements of

the experiment group, there has not been a statistically significant change before and after the exercise.

Essentially, knowing the reaction and adaptation of our bodies to exercise, the damage the exercise creates (physiology, functional anatomy, sports medicine), how our body moves (biomechanics, kinesiology) and the effect of our brain and therefore our nerve system on the events (neurology) and determining the social and psychological status of the athlete is very important for the success (Kılınç et al., 2010:21).

Performance is the score the athlete concretely presents as a result of the combination of his physical, physiological, bio-motoric, psychological, mental, technical and tactical factors. This score of the athlete is affected by more than one factor. From the training and kinesiology perspective, it is important to measure and test each factor affecting the performance and prepare the training plan and program in line with these measured values. In many sport branches, the researchers studied performance analyses with integrated approach. It is important to prepare training plans and programs as well as determining the strengths and weaknesses of the athletes (Clarys et al., 1990:242). The importance of the performance development with correct and planned training in archery sport as in all other branches arises during this training period (Wang and Landers, 1986:469).

Feeling of dominating on the arc and the arrow via hang gripping strength is important during throwing. How good an archer's domination on arc and arrow during the throw is, that much his self-confidence will boost and that decent and strong his throws will be. And this brings together a good throwing technique and success rate (Nicolay and Walker, $2005: 611,612)$. The gripping strength of the hand is accepted as an indicator of the muscle strength of the individual as well as an objective component of the functional integrity of upper extremity (Çalışkan and Gökbel, 1997:198). For humans, being able to use the left hand or both hands (ambidexterity) can 


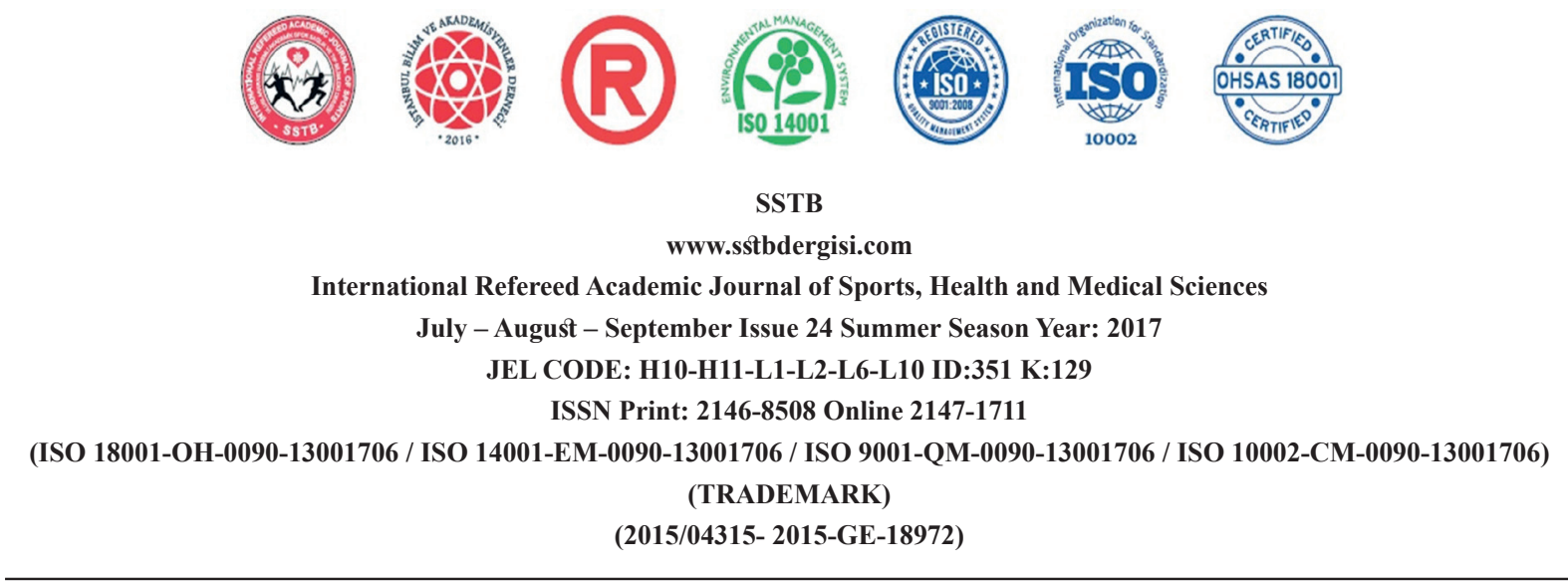

be an important advantage (İncel et al.,. 2002: 14). Considering that in many fields right hand is used with a rate of $80-90 \%$ and almost all defence and offence approaches are planned in this way, it is thought that being able to use both hands equally can be advantageous tactically and this situation can create important advantages for left hand users and ambidexter individuals. Also in archery sport, as both hands are used in gripping the arc and arrow, both right and left hand gripping strength provides advantage by playing an important role in affecting the performance and point scoring (Nicolay and Walker, 2005:612).

The effect of the strength on the success is accepted by everyone in all sports branches. The notion of the strength is misinterpreted especially by those who are not into sports and those who are but who do not closely follow the scientific development of sports. The strong athlete is generally considered to have a strong structure, is a go-getter, valiant and tough and the idea that such athletes are more successful shines. ${ }^{1}$ Today, strength and the strong athlete is evaluated by proportioning the strength per weight they create, alongside with their body structures (Castro et al., 1995: 399; Winter and Maughan, 1991). Today, a strong athlete is the athlete that has static, main, concentric, eccentric strengths, speed strength, pure (absolute) strength, strength

1 (www.antrenmanbilgisi.com, 13.10.2017). limit, relative strength, starting strength, continuity in strength, sudden movement strength, dynamic isometric strength, special strength, and functional strength and that develops these strengths at its best as required by the sport branch and use them in the best way (Yesis, 2000). Especially in weight sports, the quality and quantity of the strength gain gradually more importance. Comparing heavyweights and lightweights, it is seen that lightweights are stronger and more successful compared to heavyweights as per the test and measurements applied and the results they gain in the competitions. This is also valid in team sports (Savaş and Uğraş, 2004:264). Hand gripping strength test is a test that measures fore arm strength rather than the general physical strength and test results are more valuable for the athletes that grip, throw or move (weight lifting, baseball, etc.). Therefore, hand gripping test results of sedentary individuals and those athletes who do not specifically use fore arm strength in their branches may resemble (Gilbert and Knowlton, 1983: 138).

In a study conducted by Saka and Y1ldiz after six weeks sports training, the hand gripping strength of participants increased by $5 \%$ in both hands, and one minute push-up, sit-up and pull-up numbers of participants increased by $36 \%, 27 \%$ and $45 \%$, respectively $(\mathrm{p}<0,001)$ (Saka and Y1ldiz, 2008). In sports 


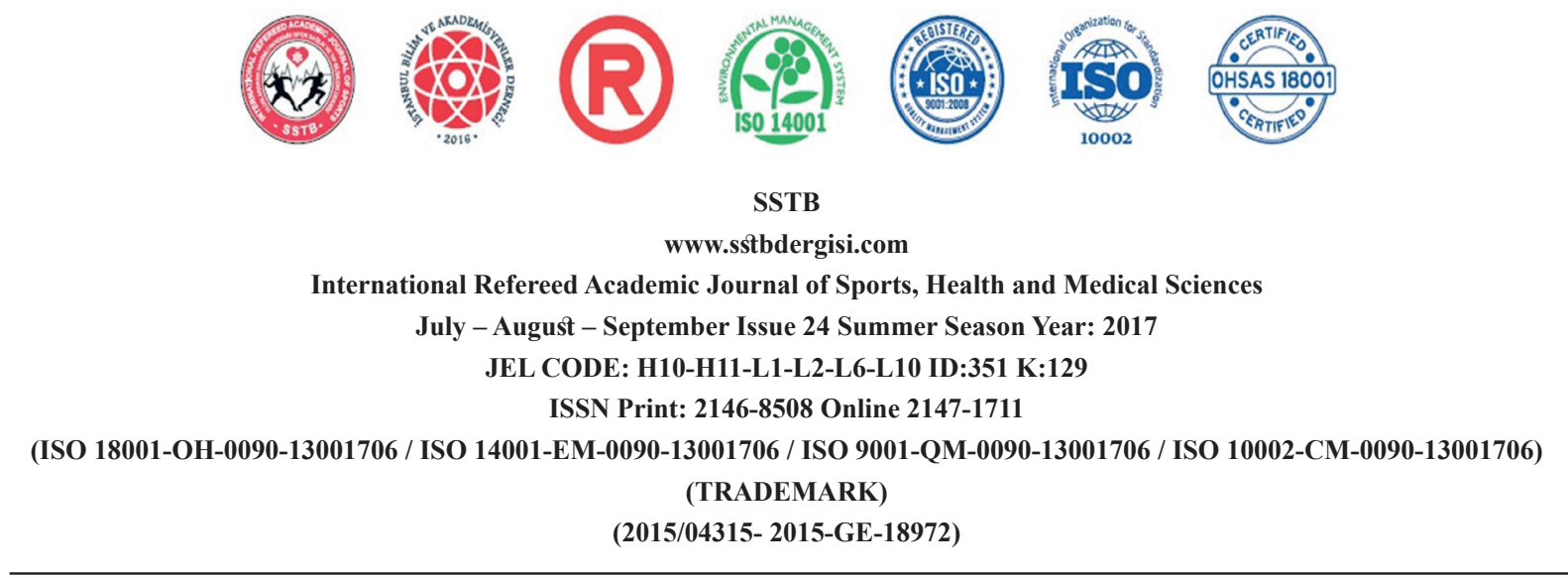

branches, the hand gripping strength is the indicator of the strength of the entire body for physical strength. Researchers state that hand gripping strength is directly related with the general strength structure and it is thought to give, in a sense, a general information about the physical strength (Niebuhr and Marion, 1990:96-101). Aydaş, in his study in 2000 on Turkey National Boxing Team $(n=10$, age $=22.7 \pm 3.3$ ), Military Police Boxing Team $(\mathrm{n}=10$, age $=22.8 \pm 1.5)$ and Bilkent University Boxing Team $(n=10$, age $=23.1 \pm 2.0)$ has found the right and left hand gripping strengths of the National Team as 45.3 and 41.9 respectively, the right and left hand gripping strengths of Military Police Boxing Team as 41.6 and 40.2 respectively and the right and left hand gripping strengths of Bilkent University Boxing Team as 44.1 and 42.8 respectively (Aydaş, 2000: 70). In the study of Sezer et al. (2017), it has been determined that the grip strength of wrist wrestlers before and after the training have been recorded and the grip strength before the training has been very well while this grip strength has reduced after the training (Sezer et al., 2017:198). Şener, in his study in 1994 named analysis on some of the conditional qualities of male swordplay national team consisting of 12 team members (age $=21.0$ ), found the unarmed (recessive) hand gripping strength of sword-players as $50.08 \mathrm{~kg}$ and armed (dominant) hand gripping strength as $53.91 \mathrm{~kg}$ on average (Şener, 1994: 48). Hazar, in a study he conducted in 1992, found the relative gripping strength of 17 elite male wrestler as $0.657 \mathrm{~kg}$. He reported the right hand gripping strength of the wrestler as $48.47 \mathrm{~kg}$ before and $52.29 \mathrm{~kg}$ after weight loss, and left hand gripping strength as $46.42 \mathrm{~kg}$ before and 48.59 $\mathrm{kg}$ after weight loss (Hazar et al., 1992). Also according to another study, after the last test, the right and left hand gripping strength of boxers were found to be $26.27 \mathrm{~kg}$ and 23.80 $\mathrm{kg}$; same were found to be $27.87 \mathrm{~kg}$ and 22.67 $\mathrm{kg}$ for taekwondo athletes and $27.87 \mathrm{~kg}$ and $27.73 \mathrm{~kg}$ for karate players (Savaş and Uğraş, 2004:257-274). Aslankeser in his study, has found the isometric strength as $153 \pm 26 \mathrm{~N}$. before the training in resting condition and as $167 \pm 66 \mathrm{n}$. after the training also in resting condition (Aslankeser, 2010: 78).

In this study, hand gripping values shows a parallel pattern with the values in the literature; however, the difference in our study is that the increase in the strength occurred after the training. In the first training, pre-exercise right hand value was $(41,4250 \pm 2,24892)$ and left hand value was $(39,2125 \pm 2,04811)$, and post-exercise right hand value was $(42,2875$ $\pm 2,24870)$ and left hand value was $(39,3938 \pm$ $2,12762)$ and these were found to be statistically significant $(p<0,05)$ in positive direction. In the second training, pre-exercise right hand value was $(43,3230 \pm 2,21614)$ and left hand 


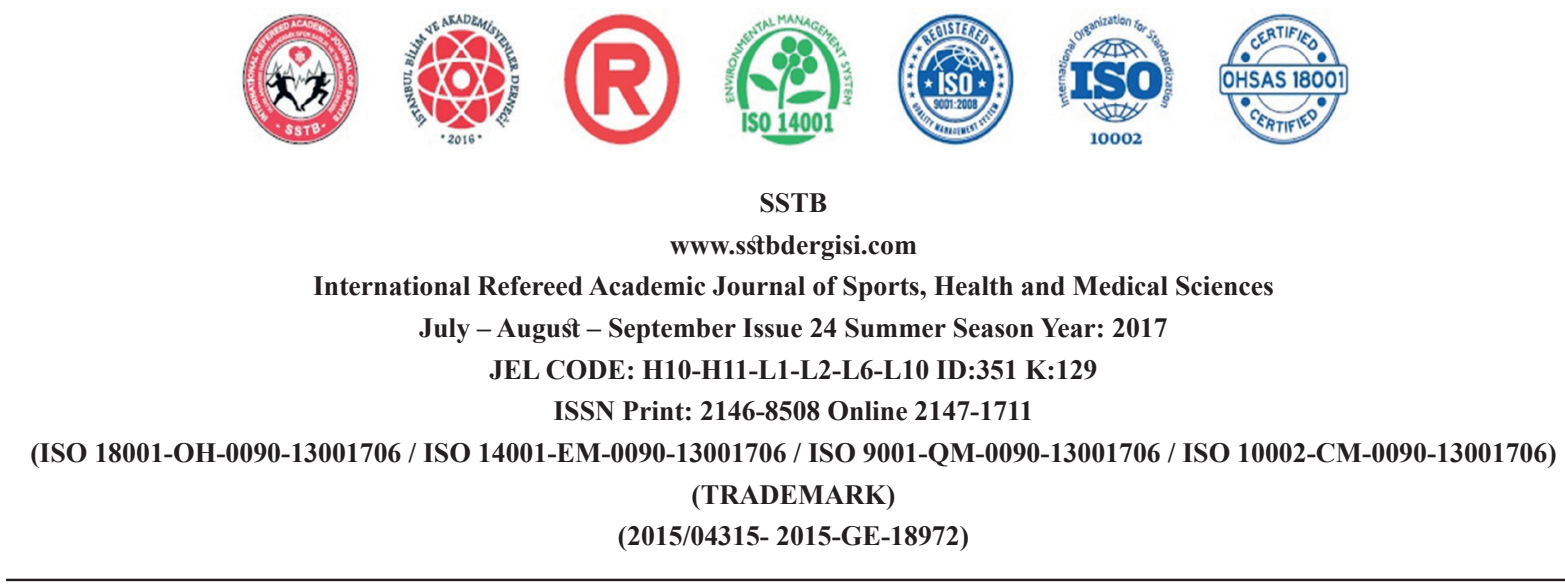

value was $(40,3145 \pm 2,02341)$, and post-exercise right hand value was $(45,1375 \pm 2,82621)$ and left hand value was $(41,3621 \pm 2,22282)$ and these were found to be statistically significant $(p<0,000)$ in positive direction. In the third training, pre-exercise right hand value was $(44,5210 \pm 2,24892)$ and left hand value was $(40,9139 \pm 2,11711)$, and post-exercise right hand value was $(45,1775 \pm 2,34211)$ and left hand value was $(41,3938 \pm 2,22137)$ and these were found to be statistically significant $(p<0,05)$ in positive direction. As in sword-players, ensuring the high motivation in arc and arrow handling habits, the intensity of the arrow handling and throwing trainings and complete intra-muscle coordination in archery can be the reasons increasing the strength. As measurements are taken during the strength training period and as the stress of the training follows at a rate of $60 \%$, it is thought that the fact that a post-exercise exhaustion does not occur, might have caused an increase in the hand gripping strength. Considering the abovementioned studies, it is seen that the hand gripping strengths of the athletes dealing with the same sports can even vary.

The aim of the physical training in archery is to gain the athlete a condition that can endure the competition conditions mentally and physically. An archer with a good physical condition is the one who developed his re- flexes, controls his muscle strength and entire body better and accordingly has a higher performance, and develops this success consistently (Atalay, 1994). Exercises that strengthen the muscles, develop the respiratory and circulatory system and increase the body flexibility are those paid most attention in physical training program of arm wrestling (Kolayiş and Mimaroğlu, 2008: 14).

In our study, the experiment group is chosen from athletes that use their right hand as the dominant hand.

The hand gripping strength measurement values of the experiment group students who were subjected to one unit training taken before and after the training were compared statistically. According to these results, the right hand gripping strength of the experiment group showed a $0.8625 \mathrm{~kg}$ and left hand gripping strength showed a $0.1813 \mathrm{~kg}$ increase after the training. This negative decrease in the strength has been determined to be statistically significant. In the second training, the right hand gripping strength of the experiment group showed a $1.8145 \mathrm{~kg}$ and left hand gripping strength showed a $1.0476 \mathrm{~kg}$ increase after the training. In the third training, the right hand gripping strength of the experiment group showed a $0.6365 \mathrm{~kg}$ and left hand gripping strength showed a 0.4799 $\mathrm{kg}$ increase after the training. These positive increases in the strength after each training 


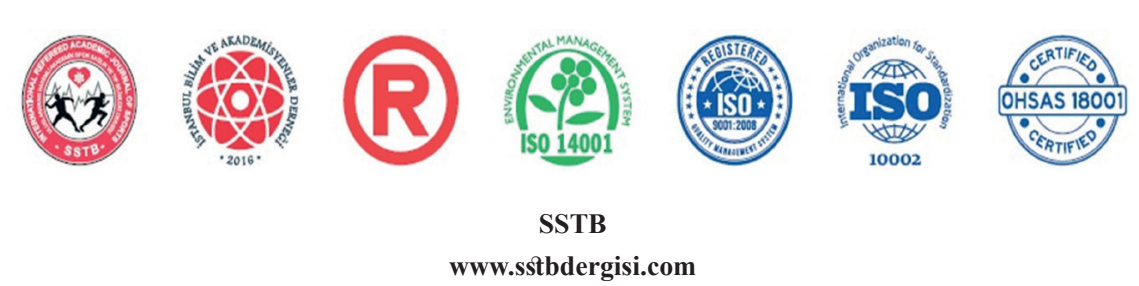

International Refereed Academic Journal of Sports, Health and Medical Sciences

July - August - September Issue 24 Summer Season Year: 2017

JEL CODE: H10-H11-L1-L2-L6-L10 ID:351 K:129

ISSN Print: 2146-8508 Online 2147-1711

(ISO 18001-OH-0090-13001706 / ISO 14001-EM-0090-13001706 / ISO 9001-QM-0090-13001706 / ISO 10002-CM-0090-13001706) (TRADEMARK)

(2015/04315- 2015-GE-18972)

have been determined to be statistically significant $(\mathrm{p}<0.05)$.

These types of studies are needed as there are limited literature knowledge on the subject and to find answers to the questions about what kinds of advantages and disadvantages the strength exercise tests of the archery athletes have.

In consequence, we can say that hand gripping strength is very important in archery sport and that it is one of the elements that affect the performance positively.

\section{REFERENCES}

ANGYAN, L., TECZELY, T., ZALAY, Z., KARSAI, Y., (2003). Relationship Of Anthropometrical, Physiological And Motor Attributes To Sport-Specific Skills. Acta Physiology Hung 90(3): ss.225-231

ASLANKESER, Z., (2010). Effects of Anaerobic Trainings on Central - Peripheral Exhaustion and Recovery Processes". Çukurova University Institute of Health Sciences Department of Physical Training and Sports Doctoral Thesis Adana

ATALAY, N., (1994). Okçuluk ve Eskrim Sporlarında Spora Bağlı Gelişen Postüral Deformiteler ve Rehabilitasyonu, Yüksek Lisans Tezi, G. Ü. Sağlık Bilimleri Enstitüsü
AYDASS, F., (2000). Comparing Selected Physical and Physiologic Characteristics of Turkey National Boxing Team and Other Boxers, Masters Thesis Ankara Universirt Institute of Health Sciences, Ankara

BICÇER S. Y. (2013). ' Effect of Reaction Speed on The Gunshot Hit Rates of Students in Police School" Aust. J. Basic \& Appl. Sci., 7(2): ss.21-32

CASTRO, M.J., MCCANN, D.J., SHAFFRATH, J.D., ADAMS, W.C., (1995). Peak Torque Per Unit Cross-Sectional Area Differs between Strength-Trained and Untrained Young Adults. Medicine and Science in Sports and Exercise, 27(3): ss.397-403

CLARYS, J.P., CABRI, J., BOLLENS, E., SLEECKX, R., TAEYMANS, J., VERMEIREN, M., VAN REETH, G., VOSS, G., (1990). Muscular Activity of Different Shooting Distances, Different Release Techniques, and Different Performance Levels, with and Without Stabilizers, in Target Archery. Journal of Sports Sciences, 8, ss.235-257

ÇALIŞKAN, S., GÖKBEL H., (1997). 'Relations between Hand Grip Power and Hand Preference with Hand Skills." Genel Tip Dergisi, 7: ss.195-203 


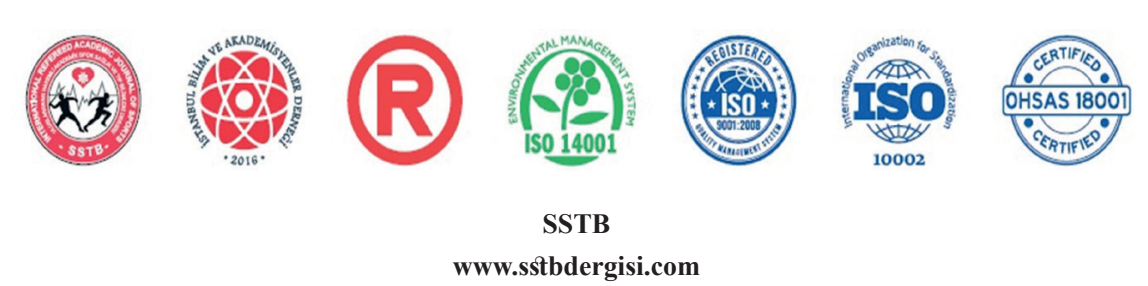

International Refereed Academic Journal of Sports, Health and Medical Sciences

July - August - September Issue 24 Summer Season Year: 2017

JEL CODE: H10-H11-L1-L2-L6-L10 ID:351 K:129

ISSN Print: 2146-8508 Online 2147-1711

(ISO 18001-OH-0090-13001706 / ISO 14001-EM-0090-13001706 / ISO 9001-QM-0090-13001706 / ISO 10002-CM-0090-13001706) (TRADEMARK)

(2015/04315- 2015-GE-18972)

EROĞLU, İ., AÇIKADA, C., TINAZCI, C., (1996). Effect of Pulse, Lactic Acid Shooting Time of National Women Archery Team on Score during Trainings, 4th Sports Science Symposium. Hacettepe University

ERTAN, H., KENTEL, B., TÜMER, S.T., KORKUSUZ, F., (2003). Activation Patterns İn Forearm Muscles During Archery Shooting Human Movement Science, 22: ss. $37-45$

ERTAN, H., KENTEL, B.B., TÜMER, T., (2005). Reliability and Validity Testing of an Archery Chronometer. Journal of Sport Science and Medicine, 4, 95-104

\section{FITA TÜZÜĞ $\ddot{U}$ VE KURALLARI-KITAP 3}

(2006). Rules of Indoor Target Archery (Ertan, H., Yapar, A. Çev. Ertan, E. Ed

GILBERT, J.C., KNOWLTON, R.G., (1983).

'Simple Method To Determine Sincerity Of Effort During A Maximal İsometric Test Of Grip Strength.” Am J Phys Med; 62: ss.135-144

HAZAR, M., AYDOS, L., ELBEK SS., DURMUSS O., (1992). The effect of falling of weight on Serum Testosterone and Cortisol Levels in Wrestlers and the relation with Endurance, Quick strength and Maxvo2. Hacettepe University, 2. Natio- nal SporT Sciences Congreess Abstracts, Ankara

INCEL, N.A., CECELI E., DURUKAN B.P., ÖKEN Ö., ERDEM R.H., (2002). ' $E v a-$ luation of Effects of Sex and Hand Dominance on Hand Grip Power." Romatizma, 17 (1) ss. $12-16$

KARANFILCCI, M., KABAK, B., HAMAMCILAR, O, ARSLANOĞLU, E., (2014). Okçulukta spor yaralanmaları, Spor Genel Müdürlüğü, Sağlık İşleri Dairesi Başkanlığı yayınları, Ankara

KILINÇ, F., CESUR, G., ATAY, E., ERSÖZ, G., KILIÇ, T., (2010). Study on Physical, Physiologic and Force Factors that Affect Technical Shooting Performances of 10-14 Age Group Elite Female Archers. S.D.Ü. Tip Fak. Derg: 17(3) /18-24

KOLAYIŞ, EROĞLU, I., MIMAROĞLU, E., (2008). Effects of Pulse and Aiming Speed of Archery National Team on Shooting Score during Training Environment. Uluslararası İnsan Bilimleri Dergisi 5(1):1-18

MANN, D.L., LITTKE, N., (1989). Shoulder injuries in Archery. Canadian Journal of Sport Sciences 14(2): ss. 85-92

NIEBUHR, B., MARION, R., (1990). Voluntary Control Of Submaximal Grip Strength. Am J Phys Med Rehabil, 69: ss.96-101 


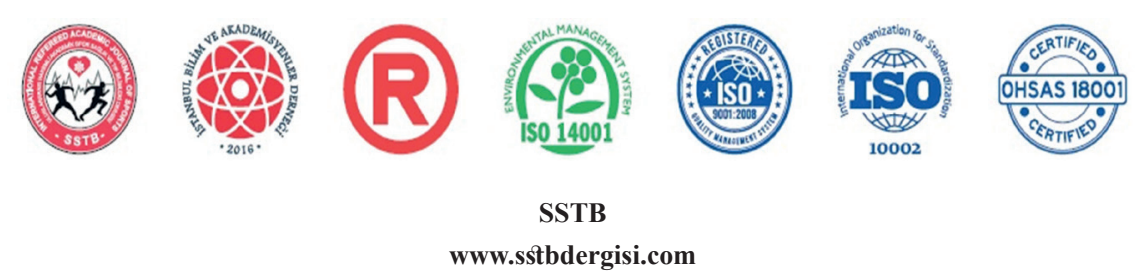

International Refereed Academic Journal of Sports, Health and Medical Sciences

July - August - September Issue 24 Summer Season Year: 2017

JEL CODE: H10-H11-L1-L2-L6-L10 ID:351 K:129

ISSN Print: 2146-8508 Online 2147-1711

(ISO 18001-OH-0090-13001706 / ISO 14001-EM-0090-13001706 / ISO 9001-QM-0090-13001706 / ISO 10002-CM-0090-13001706) (TRADEMARK)

(2015/04315- 2015-GE-18972)

NICOLAY, C.W., WALKER, A.L., (2005).

"'Grip Strength And Endurance: Influences Of Anthropometric Variation, Hand Dominance, and Gender." Int J Ind Ergon; 35: ss.605-618

ÖZDAMAR, K., (1999). "Statistical Data Analysis with Package Programs" Kaan Kitabevi, Eskişehir

ÖZER, K., (1992). Anthropometric Measurements, Kazancı Matbaası, İstanbul

SAKA, T., YILDIZ, Y., (2008). Effects of Sport School Curriculum on Some Anthropometric and Functional Tests in Young Males, Niğde Üniversitesi Beden Eğitimi Ve Spor Bilimleri Dergisi Cilt 2, Sayı 1

SAVAŞ S., UĞRAŞ A., (2004). Effects of Eight-Weeks of Pre-season Trainings on Physical and Physiologic Characteristics of Male Box, Taekwondo and Karate Students in Universities." 'Gazi Eğitim Fakültesi Dergisi, Cilt 24, Say1 3, ss.257274

SEZER, S.Y., ÇELIKKLL, B.E., YÜCEL, A.S., KARADAĞ, M., SAVUCU, Y.,
(2017). Birim Antrenmanin Bilek Güreşçilerin El Pençe Kuvvetine Etkisi Journal Of Educational and Traning Studies 5(6): ss.196-201

SENER, H., (1994). To investigation some conditional properties of Fencing National team athletes. master thesis, Ankara

WANG, M.Q., LANDERS, D.M., (1986). Cardiac Response and Hemispheric Differentation During Archery Performance: A Psycophysiological Investigation. Psycophysiology, 23: s.469

WINTER, E., MAUGHAN, R.J., (1991). Strength and Cross-Sectional Area of the Quadriceps in Men and Women. Journal of Physiology-London. 438: ss.175-175

YESIS M., (2000). The Many Faces of Strenght. California State University, Fullerton

\section{INTERNET SOURCES}

http://www.antrenmanbilgisi.com/relatifkuvvet/, Erişim tarihi: 13.10.2017

http://bilginaticilik.com/?page_id=64, erişim tarihi: 11.10.2017. 